\title{
(UKRYTE) ZAANGAŻOWANIE I (POZORNA] NEUTRALNOŚĆ: STRUKTURALNE OGRANICZENIA ROZWOJU SOCJOLOGII KRYTYCZNEJ W WARUNKACH PÓŁPERYFERYJNYCH
}

Tomasz Warczok

Uniwersytet Pedagogiczny w Krakowie

Tomasz Zarycki

Uniwersytet Warszawski

\section{/// Wprowadzenie}

W niniejszym tekście zajmiemy się kwestią zaangażowania i neutralności w kontekście wybranych praktyk w polskim uniwersum socjologicznym ${ }^{1}$. W szczególności chcielibyśmy postawić tezę, iż w warunkach (pół) peryferyjnych, do jakich można odnieść pozycję Polski, dominującą rolę odgrywają w socjologii nurty ściśle powiązane z logiką pola politycznego, a szerzej tak zwanego pola władzy. W takich warunkach zaangażowanie w formach, które nie korespondują bezpośrednio z politycznie wyznaczonymi wzorcami krytyki społecznej, staje się wysoce utrudnione. Chcielibyśmy zadać więc pytanie, dlaczego to, co zwie się „socjologią krytyczną”, mająca na celu demistyfikację istniejących relacji władzy, jest w polskim polu socjologicznym marginalizowane, a „socjologia praktyczna” bądź, mówiąc inaczej, „służebna”, w niektórych odsłonach skupiająca się na legitymizacji i naturalizacji aktualnego porządku społeczno-politycznego, zdaje się mieć status socjologii tout court. Twierdzimy, że nawet jeżeli dochodzi do krytyki społecznej, to ma ona na tyle wybiórczy charakter, że $\mathrm{w}$ istocie stanowi ukryte uzasadnienie status quo.

Szukając społecznej genezy socjologicznego myślenia, odwołujemy się tutaj do czterech typów socjologii wprowadzonych przez Michaela Burawoya (2009). Przypominijmy, że Burawoy zaproponował, by socjologię publiczną odróżnić od trzech innych typów socjologii: profesjonalnej,

\footnotetext{
1 Artykuł powstał w ramach projektu finansowanego przez Narodowe Centrum Nauki (NCN) nr DEC-2012/05/B/HS6/00834.
} 
praktycznej/służebnej (policy) oraz krytycznej. W jego rozumieniu socjologie profesjonalna i praktyczna mają się zajmować opisywaniem społeczeństwa bez szczególnej refleksji nad mechanizmami tworzonej przez siebie wiedzy, mają dostarczać wiedzy instrumentalnej, użytecznej do rozwiązywania konkretnych, pragmatycznych problemów. Socjologie publiczna i krytyczna zaś są w tym układzie socjologiami refleksyjnymi, poddającymi namysłowi nieoczywiste założenia stojące za zdroworozsądkową wiedzą o społeczeństwach oraz niewidoczne mechanizmy funkcjonowania samych społeczeństw. Paradoksalnie, w polskich, lokalnych warunkach, inaczej niż w opisywanym przez Burawoya amerykańskim kontekście, szczególnie społecznie widzialne są socjologia praktyczna oraz socjologia publiczna, która wszelako nie jest socjologia krytyczna, przeciwnie - staje się nierzadko socjologią apologetyczna. Socjologia praktyczna/służebna wspierana i finansowana jest pośrednio lub bezpośrednio przez biznes (konsulting, badania rynkowe itd.), socjologia publiczna zaś, a właściwie jej szczególna nie-krytycz̨na postać, która bliska jest „,socjologicznemu dziennikarstwu" (Wacquant 2004), jest realizowana dzięki specyficznej symbiozie świata naukowego, medialnego i politycznego.

Aby wyjaśnić zidentyfikowany przez nas w Polsce paradoks i rozpoznać społeczne warunki specyficznego niekrytycznego zaangażowania socjologa i jednoczesnej marginalizacji krytyki właściwej, sięgniemy po narzędzia teoretyczne Pierre'a Bourdieu, zwłaszcza po jego teorię pola władzy. Zakładamy bowiem, że źródeł praktyk symbolicznych - dyskursów, idei, a także teorii naukowych - należy szukać w specyficznych konfiguracjach strukturalnych. Wszelkie symbolizacje odpowiadaja określonym strukturom społecznym. Przy czym nie chodzi tu o proste odbicie „baza-nadbudowa”, ale istnienie relatywnie autonomicznych uniwersów, zwanych przez Bourdieu „polami”, które są w jego wizji zasadniczymi kontekstami jakiejkolwiek produkcji symbolicznej-określającej jej kształt, wartość i znaczenie.

\section{/// Socjologia w metapolu władzy a dominacja inteligencji}

Według Pierre’a Bourdieu (Bourdieu i Wacquant 2001) każde pole stanowi obszar społecznych zmagań, walki, której efektem jest zazwyczaj wyłonienie się w nim podziału na część dominującą i zdominowaną. Odnosi się on do wszystkich pól (politycznego, religijnego, artystycznego, prawnego itd.), w tym pola socjologicznego. Zmagania te maja charakter symboliczny, narzędziem i stawką jest więc narzucenie określonej wizji świata, w tym wypadku określonych teorii, paradygmatów, a nawet 
metodologii. Wystarczy przywołać tutaj walki między przedstawicielami poszczególnych szkół, które strukturalnie układają się w przeciwstawne pary: socjologia ilościowa $v$. socjologia jakościowa, obiektywizm vs. subiektywizm, mikro v. makro itd. (Bourdieu 1988). Dominującymi są ci, którzy dysponuja największą ilościa kapitału naukowego w danym polu, zdominowani maja go odpowiednio mniej. Przy czym sama definicja tego kapitału (taka czy inna teoria) także jest przedmiotem walki symbolicznej.

Oprócz podziału na część dominującą (ortodoksyjna) i zdominowaną (w pewnych warunkach heretycka) istnieje też podział na część autonomiczną i heteronomiczną (Bourdieu 1993b, 2001a, 2001b). Innymi słowy, chodzi o równoległy podział na część zależną od zewnętrznych sił (przede wszystkim ekonomicznych i politycznych) i część relatywnie od nich niezależna. W polu artystycznym odpowiada to podziałowi na obszar sztuki komercyjnej oraz „poszukującej”, „niezależnej” (kierującej się hasłem „sztuka dla sztuki”). Na zasadzie homologii (czyli podobieństwa w różnicy, zob. Bourdieu 2001a) w polu socjologicznym do czynienia mamy, z jednej strony, z badaniami typowo komercyjnymi (analizy rynku, sondaże opinii) lub służącymi celom politycznym (doradztwo polityczne) oraz z drugiej strony, z relatywnie niezależnymi, rozwijającymi samą teorię socjologiczną. Ważne jest, że zakres jednego bądź drugiego obszaru jest uzależniony od generalnego położenia pola socjologii (tak jak każdego innego) w metapolu władzy. Przypomnijmy, że pojęcie pola władzy wprowadzone zostało do literatury przez Bourdieu jako rozwinięcie kategorii „elity”, zastępujące równocześnie to, co wcześniej zwane było „klasą rządzącą” (Bourdieu 2009; Bourdieu, Wacquant 1993). Dzięki temu pojęciu możliwe jest rozpatrywanie przestrzeni działania aktorów uprzywilejowanych w danym społeczeństwie jako zróżnicowanego pola podmiotów o różnych orientacjach i zasobach. Choć pole władzy generuje ostre podziały społeczne, polityczne i kulturowe, a aktorzy z jego przeciwnych biegunów moga być silnie skonfliktowani, to samo jako całość, a nie poszczególne jego frakcje, może być rozpatrywane jako sfera dominująca w każdym społeczeństwie. W szczególności w polu władzy ustalane są kluczowe osie podziałów politycznych i ich znaczenia. Tam też negocjowane są dominujące w danym społeczeństwie logiki hierarchii społecznych i zasady legitymizacji nierówności społecznych.

Pole władzy rozciąga się więc od pola ekonomicznego do pól produkcji kulturowej (pola religijne, artystyczne, naukowe - w tym pole socjologiczne), z położonym pośrodku polem administracyjnym (administracja rządowa, samorządowa itd.) oraz do pewnego stopnia zespolonego z tym ostatnim polem politycznym (Bourdieu 1996). Im bliżej pola ekonomicznego 
i politycznego, tym autonomia danego uniwersum jest mniejsza. Z tego też względu przykładowo pole medialne jest mniej autonomiczne (zależne do sił ekonomiczno-politycznych) niż pole matematyki czy pole poezji (por. Bourdieu 2005c).

Jako że nie istnieja ponadhistoryczne, szczegółowe reguły funkcjonowania pól (Bourdieu, Wacquant 2001), konieczne jest za każdym razem odtworzenie układu pól w danym lokalnym kontekście. Pamiętać więc trzeba, że całość ulokowania polskiego pola władzy ma charakter półperyferyjny, ponieważ Polska jako państwo taką właśnie pozycję zajmuje w systemie-świecie, rozumianym wedle definicji Immanuela Wallersteina (1974). Bez żadnej watpliwości ma to - o czym nie zawsze się pamięta ogromny wpływ na strukturyzację poszczególnych pól oraz całości pola władzy. Charakterystyczna dla peryferii i półperyferii słabość instytucji państwowych (ibidem) musi skutkować ograniczoną autonomia pól naukowych. W porównaniu z krajami rdzenia systemu światowego wsparcie finansowe ze strony państwowego pola administracyjnego jest nader skromne, co widać dobrze, zarówno jeżeli chodzi o płace uczonych, jak i finansowanie samych badań. Jednak dla elity pola socjologicznego problem ten znalazł swoje pragmatyczne rozwiązanie. Większość jej przedstawicieli, korzystając ze swojej uprzywilejowanej roli inteligenckich autorytetów, podejmuje pracę równocześnie w kilku różnych instytucjach, ma także dochody z różnego rodzaju zajęć dorywczych, świadczenia usług, w szczególności eksperckich, dla podmiotów zarówno publicznych, jak i gospodarczych, krajowych i często międzynarodowych. Mechanizm ten łagodzący problemy materialne, a wręcz pozwalający elicie pola inteligenckiego żyć na poziomie porównywalnym do tego, na którym funkcjonuja przeciętni jej koledzy z krajów zachodnich, niesie za sobą dodatkowe uzależnienie pola socjologicznego od innych, bardziej zasobnych w kapitał ekonomiczny sektorów pola władzy. Nie jest to zwykle zależność bezpośrednia, przedstawiciele elity pola socjologicznego nie są zwykle „opłacani” za wygłaszanie konkretnych opinii, nie sa też wszyscy zwykłymi ekspertami do wynajęcia, jak na przykład ich koledzy pracujący w licznych firmach consultingowych. Musza jednak mieć praktyczną świadomość, że wyraźne i trwałe trwanie przy poglądach niekorespondujących z wizjami świata dominującymi w instytucjach, dla których pracuja, może doprowadzić do pozbawienia ich płynących z nich ważnych źródeł dodatkowych dochodów oraz wzmocnienia statusu społecznego.

Efektem strukturalnym tego stanu rzeczy jest właśnie znaczny rozwój socjologii praktycznej/służebnej na niekorzyść socjologii krytycznej - w założeniach najbardziej autonomicznej. Jednocześnie ze słabo 
rozwiniętym lokalnym polem ekonomicznym (co znowu jest właściwe dla całości obszarów półpereferyjnych i peryferyjnych), a więc praktyczna nieobecnością burżuazji (Eyal, Szelényi, Townsley 1998) związana jest znowu, nie zawsze należycie dostrzegana - dominacja inteligencji w polskim polu władzy (Zarycki 2009). Ma to ogromne znaczenie dla strukturyzacji całości pola władzy oraz pozycji socjologów w nim jako modelowych inteligentów ${ }^{2}$.

Postawimy tu więc szerszą tezę, iż wykształcone historycznie w warunkach braku własnej państwowości (okres zaborów oraz okupacji) lub jej widocznej słabości i zależności polskie pole władzy jest strukturalnie zdominowane przez elity inteligenckie. Jak wiadomo, wykształciły się one w dużym stopniu ze środowisk zubożałej szlachty (Chałasiński 1958), jednak nie można jej utożsamiać z zachodnią burżuazja ani klasą średnia, definiująca swój status przede wszystkim w kategoriach kapitału ekonomicznego. Z drugiej strony, środkowoeuropejska inteligencja nie może być sprowadzona do kategorii osób mających wyższe wykształcenie czy też intelektualistów (Gella 1976). Jednocześnie elity ekonomiczne oraz

${ }^{2}$ W kontekście słabości lokalnego pola ekonomicznego najbardziej stabilną w kategoriach tzn. długiego trwania elitą jest właśnie elita inteligencka, której jednoznaczna dominacja w polskim polu władzy sięga co najmniej roku 1918 (Jedlicki 2008). Inteligenci wchodzą w rolę naukowców i intelektualistów, urzędników i polityków, artystów i dziennikarzy, przedsiębiorców i menedżerów oraz wielu innych. Role te nie są jednak dla inteligencji podstawowymi wymiarami jej statusu, który związany jest przede wszystkim z tym, co w języku Bourdieu nazywać można kapitałem kulturowym. Mowa tu o specyficznym kapitale kulturowym wytwarzanym przez inteligenckie milieu spajane także silnymi więzami kapitału społecznego opartego na bliskich więziach towarzyskich, środowiskowych, nierzadko rodzinnych. Nie brak w tych środowiskach wielopokoleniowych rodzin inteligenckich, których pamięć sięga szlacheckich korzeni i przodków wchodzących w role inteligenckie w drugiej połowie XIX wieku (np. Bajer 2013). Tak skonstruowane milieu jest w dużym stopniu odporne na zawirowania polityczne i gospodarcze charakterystyczne dla tej części Europy. Elity inteligenckie dzięki oparciu się na kapitałach kulturowym i społecznym i kontrolując w ten sposób polskie pole władzy, zabezpieczone są w swojej dominacji przed nagłymi załamaniami w wymiarach ekonomicznym czy politycznym. Taka konfiguracja pola władzy daje polskim elitom inteligenckim niezwykle uprzywilejowana pozycję. Można ją w języku Pierre’a Bourdieu ująć jako dominację kapitału kulturowego zarówno nad kapitałem politycznym, jak i kapitałem ekonomicznym. Ten ostatni jest oczywiście obecnie kluczowym zasobem, nie stanowi jednak zasadniczego pola gry dla elit polskich. Kontrolujące większość jego pola zachodnie elity ekonomiczne nie sa jednocześnie w stanie używać swojej przewagi gospodarczej w sposób bezpośredni na innych polach, ponieważ zbyt radykalne ruchy w tej płaszczyźnie mogłyby być odebrane jako ingerencja obcego kapitału w „sprawy polskie”. Do legitymizacji takich działań potrzebne jest więc symboliczne pośrednictwo inteligencji, która może im nadawać prawomocność, czy to powołują się na wyzwania „modernizacji”, czy też „interesu narodowego”, które sama jest w stanie definiować. 
administracyjno-polityczne są zwykle zbyt słabe, by w warunkach środkowoeuropejskich stanowić istotną opozycję dla inteligencji. Pozostając pod jej symbolicznym wpływem, same w mniejszej lub większej części przyjmują inteligenckie tożsamości i próbują włączyć się do dominującej w polu władzy inteligenckiej gry. W przeciwieństwie do konfiguracji obserwowanych zarówno w większości krajów zachodnich, jak i w Rosji, gdzie pola władzy tworzone sa przede wszystkim przez silne państwo, w Polsce to wyższa inteligencja, czy też szerzej elita kulturowa, okazuje się głównym koordynatorem pola władzy. A zatem można powiedzieć, że w polskich (pół)peryferyjnych warunkach, w lokalnym polu władzy, bieguny ekonomiczny (globalny) i kulturowy są położone dość blisko siebie, bardziej zorientowane na symbiozę i współpracę niż konflikt. Ten ostatni odbywa się wyraźnie na innym poziome, dzieląc siły „postępowe”, „modernizujące”, procentrowe od „tradycyjnych”, „konserwatywnych” („narodowych”, „nacjonalistycznych”) nastawionych co najmniej sceptycznie wobec sił centrum (eurosceptycyzm itd). Podział taki może być obserwowany $\mathrm{w}$ wielu innych krajach peryferyjnych i semiperyferyjnych, a w polskim polu władzy dzieli również samą inteligencję na frakcje procentrową (obecnie dominująca) i zdominowana frakcje peryferyjnac. Ta pierwsza nawiązuje do „progresywnych” tradycji inteligencji (Walicki, 2005), definiując swoją rolę społeczną w kategoriach ,awangardy” i nośnika zmian (w rozumieniu weberowskiego Träger, Weber 2002), czyli grupy mającej na celu zbliżenie się do centrum systemu światowego („,modernizacji” i „unowocześnienia”), w praktyce przyjmuje funkcję typowo kompradorska. Zapewnia, świadomie bądź nie, kulturową „obsługę” kapitału płynącego z centrum (globalnego pola ekonomicznego) (Drahokoupil 2008). W swoich przedstawieniach symbolicznych, licznych teoriach, nawet czysto naukowych, kreśli nie zawsze wypowiedziane wprost wizje postępu, w których perspektywa epistemologiczna jest nierozdzielna od eschatologicznej (por. Alexander 2010). Przy okazji niejako, zgodnie z nieujawnionym religijnym trybem, dzieli jednostki lub nawet całe grupy na „zbawionych” (,nowoczesnych”, idących za postępem i mających ku temu odpowiednie „kompetencje”) oraz „potępionych” („tradycyjnych”, mentalnie i materialnie ,zacofanych”).

Strukturalne położenie (pół)peryferyjnego pola władzy sprawia, że rola kompradorska staje się dominująca w wielu indywidualnych polach, zarówno ekonomicznych, jak i kulturowych. Z drugiej strony, w odpowiedzi na tak rozumianą kompradorską ortodoksję pojawiają się aktorzy, przede wszystkim w grupie szeroko rozumianej inteligencji, którzy przeciwstawiają się podobnie rozumianemu „unowocześnieniu” i „zbliżeniu” 
do centrum. Lokują się w kontrze do sił procentrowych i definiują w kategoriach „sceptycyzmu” (np. „eurosceptycyzm”), a nawet odrzucenia tego, co „globalne”, „kosmopolityczne” („obrona interesu narodowego”). Konsekwentnie i czysto relacyjnie widzą się jako „tradycjonaliści” i „konserwatyści” (jako odpowiedź na „nowoczesność” procentrowych modernizatorów). Wspólną cechą tej heterodoksyjnej grupy jest akcent (z niewielkimi wyjątkami) na kwestie kulturowe, z pominięciem lub marginalnym traktowaniem problematyki ekonomicznej ${ }^{3}$. Jednocześnie w sporach między inteligencką ortodoksją a heterodoksją istnieje milczący obszar porozumienia, zapewniający inteligencji jako takiej, bez względu na pozycję w polu, dominację w całej sferze społecznej. Opiera się on na stale odtwarzanym (choć w zmieniającej się formie), postszlacheckim schemacie „pan/cham”. Co ważne, taka znaturalizowana klasyfikacja jest także udziałem inteligencji „konserwatywnej”, nastawionej „tradycyjnie”4.

3 Wraz z przekształceniami w polu politycznym zmieniał się, do pewnego stopnia, układ całości pola władzy, zwłaszcza zaś polityka symbolizacji - dominujące dyskursy, formy klasyfikacji itd. I tak schematycznie można powiedzieć, że grosso modo do roku 2005 dominował „podział postkomunistyczny” (Grabowska, 2004) z kluczowa, negatywną figura homo sovietucus jako zaprzeczeniem wszystkiego tego, co na poziomie społecznym i osobowościowym pożądane, aby zbliżyć się do centrum (przedsiębiorczość, otwartość, elastyczność itd.). Później taksonomia ta nabrała nowych znaczeń - w miejsce homo sovieticus pojawił się tradycjonalny „populista” stanowiący zaprzeczenie liberalnego obywatela. Część „tradycjonalna” i sceptyczna wobec sił centrum odwracała tę klasyfikację, pozytywnie waloryzując „,tradycję”, oskarżając „liberałów” o zdradę narodową. Podział ten ma charakter powtarzalny i spotkać go można w wielu półperyferyjnych polach. Od pola politycznego (PO vs. PiS), przez medialne („Gazeta Wyborcza” vs. „Rzeczpospolita”; „Polityka”, „Wprost”, „Newsweek” vs. „Uważam Rze”, „wSieci”, „Do Rzeczy”), aż do religijnego (Kościół otwarty vs. 'zamknięty'; „Tygodnik Powszechny” vs. „Nasz Dziennik”). Im pola bardziej heteronomiczne, tym wymienione podziały są bardziej wyraźne. Dlatego też klarowniejsze będa w polu medialnym niż w relatywnie bardziej autonomicznym polu socjologicznym. Ponieważ każde z pól ma własną historię, własną temporalność, nie musi w sposób automatyczny i natychmiastowy dopasowywać się do zmian ideologicznych w polu politycznym czy medialnym. Można rzec, że im dane pole bardziej autonomiczne, tym mniejsza skłonność do natychmiastowego dopasowania. Fakt ten może tłumaczyć, dlaczego przedstawienia symboliczne w polu socjologicznym nie odpowiadają w sposób dokładny temu, co dzieje się w polach polityczno-medialnych. Mimo że takie wpływy istnieją, charakteryzują się zazwyczaj pewnym opóźnieniem, wynikającym właśnie z relatywnej autonomii tego pola.

4 Już ponad pół wieku temu Józef Chałasiński pisał: „Kultura duchowa i kultura materialna! Nigdzie to przeciwstawienie nie nabrało takiej jaskrawości jak u nas i nigdzie nie wiązało się tak jaskrawo ze strukturą społeczną - inteligencja, czyli wyższa sfera ducha i masy ludowe - sfera materialna; inteligencja - polscy Europejczycy i lud - polscy Murzyni [...]" (Chałasiński 1958: 113-114). Zarysowane przeciwstawienie ,inteligencja/lud” szczególnie ostre jest w przypadku dominującej inteligencji procentrowej; inteligencja sceptyczna 
Istotne jest zrozumienie, iż to, co czasem określa się mianem „pęknięcia” w społeczeństwie, istnienia „dwóch narodów” (opisywanego czasem jako „dwie Polski”) czy też „dualnej struktury społecznej”, dzielącej je na część „nowoczesną” i „tradycyjna”, jest wyobrażeniem powstającym w polach produkcji symbolicznej (medialnym, naukowym, religijnym itd.), niekoniecznie zaś opisem czy też diagnozą realnych procesów dziejących się w szerszej przestrzeni społecznej (Éber 2011). Jest to zgodne z myśla Pierre'a Bourdieu (Bourdieu, Wacquant 1993), iż wiele walk, które wydaja się walkami klasowymi, pozostaje w istocie zmaganiami wewnątrz pola władzy. Owe wyobrażenia, wizje świata (naukowe, dziennikarskie) są więc związane z określonymi pozycjami, interesami i podziałami wewnątrz pola władzy. Co ważne jednak, opisywane wizje świata, w tym wypadku naukowe, współtworzą rzeczywistość, którą zdają się opisywać, gdyż, jak przypomina Bourdieu (2008), sama rzeczywistość to nie tylko regularności praktyk społecznych (pozycji, interesów, poszczególnych zasobów, ulokowanych zgodnie z porządkiem klasowym), ale także towarzyszące im symbolizacje. Symbolizacje (zasadnicze wyobrażenia na temat podziałów świata społecznego) powstające w polu władzy mają szczególną moc, gdyż - o czym już była mowa - w tym właśnie miejscu dokonuje się kluczowa dystrybucja znaczeń społecznych (media, pole naukowe, pole polityczne, państwowe, pole administracyjne itd.).

\section{/// Pole socjologiczne}

Pole socjologiczne w Polsce, jak powiedziano, odznacza się dość słabą autonomia. Z tego powodu, paradoksalnie, socjologowie polscy są nie tylko niezwykle widoczni w mediach (Kilias 2007), ale, co ważne, dość łatwo i jak można sądzić, niepostrzeżenie przejmują myślenie w trybie politycznej doksy ${ }^{5}$. Mówiąc inaczej, ze względu na bliskość pola medialnego

wobec centrum, jak wszystkie konserwatyzmy, będzie w swym dyskursie podkreślać wartość „przyzwoitego” (prostego) „ludu” (Bourdieu 1991a). Przy czym „przyzwoitość” zasadza się tu na znaturalizowanym podporządkowaniu istniejącej hierarchii.

5 Doksę utożsamiać można ze „zdrowym rozsądkiem”, zbiorem „,[...] potocznych przeświadczeń podzielanych przez wszystkich” (Bourdieu 2006: 140). Doksa złożona jest z dychotomicznych klasyfikacji (wysokie/niskie, kobiece/męskie, silne/słabe, elitarne/masowe itd.), które stanowią swoiste okulary poznawcze, organizujące postrzeganie świata. Dla nas szczególnie interesująca jest „doksa intelektualna”, gdyż wbrew temu, co może się wydawać, intelektualiści, w tym socjologowie, także myślą o świecie wedle niepomyślanych, znaturalizowanych kategorii mentalnych. Te zaś mają ścisłe pochodzenie społeczne. „Doksa intelektualna” definiowana jest jako „[...] zbiór relatywnie usystematyzowanych słów, wyrażeń, sloganów, kwestii i debat, których podzielana oczywistość określa to, 
i politycznego socjolodzy (a przynajmniej ich część) zaczynają posługiwać się strukturami mentalnymi dominującego porządku politycznego.

Znacząca liczba polskich socjologów, a również innych naukowców społecznych, w szczególności psychologów społecznych, politologów czy etyków, należy do grona gwiazd medialnych pojawiających się regularnie zarówno na łamach prasy drukowanej, jak i mediów elektronicznych. Co więcej, wypowiedzi czy artykuły wielu z nich często stają się ważnymi ,wydarzeniami medialnymi”. O ustosunkowanie się do nich proszeni są kluczowi politycy, przedstawiciele instytucji publicznych czy przedsiębiorcy. W tym sensie można postawić tezę, że „socjologia publiczna” jest w Polsce rozwinięta relatywnie dobrze. Socjologowie, ci rozpoznawani publiczne, sa uważnie słuchani, często pojawiają się w mediach i mają wymierny wpływ na życie społeczne i polityczne w Polsce. Dzięki tym mechanizmom szersze zainteresowanie udaje się niejednokrotnie wzbudzić dzięki medialnym wypowiedziom wokół wyników konkretnych badań naukowych czy poszczególnych publikacji. Na łamach gazet nie brak debat intelektualnych, których ważnymi uczestnikami są socjologowie. Ta niedoceniana często w Polsce pozycja „socjologii publicznej” w naszym kraju wiąże się też z określonymi problemami. Jako pierwszy z nich można wskazać silne upolitycznienie debat publicznych związane ze wspomnianym już ostrym pęknięciem w polu władzy. Powoduje to, po pierwsze, że socjologowie zapraszani są na scenę publiczną, w szczególności do pola medialnego czy pola politycznego, z oczekiwaniem, że wpiszą się w aktualny podział „,pracy ideologicznej” w polu władzy, że dostarczą naukowych argumentów na rzecz racji jednej bądź drugiej strony głównego sporu. W efekcie większość z dość licznych medialnych socjologów nie tylko pojawia się na scenie publicznej w przewidywalnych kontekstach, ale dość przewidywalne sa w określonych okresach oceny, jakie przedstawiają. A oczekuje się od nich zwykle normatywnych diagnoz, prostych rekomendacji i jasnych osądów o charakterze de facto politycznym czy moralnym oraz potwierdzenia podsuwanych przez polityków czy dziennikarzy tez. Osoby niewpisujące się we wspomniane wyraźne podziały są zapraszane do sfery publicznej znacznie rzadziej. Mechanizm ten ma dużo dalej idące konsekwencje. Powoduje, że podziały z pola władzy, najwyraźniej wyrażone w polu politycznym, gdzie jest to w miarę naturalne, przenoszą się ze zdwojoną siłą również na pole naukowe, a w szczególności na pole socjologiczne. W efekcie sposób myślenia socjologów o społeczeństwie zaczyna silnie korespondować

co wyobrażalne i umożliwiające komunikację. Stanowi produkt zbiorowych i anonimowych wymian [...] między dziennikarzami a intelektualistami [...] (Pinto 2009: 6). 
z logiką dwu głównych biegunów pola władzy. Z jednej strony, mamy więc do czynienia, jak już wspomnieliśmy, ze specyficzna forma paradygmatu modernizacyjnego, w myśl którego oświecona elita, na czele z inteligencja, w tym z socjologami, diagnozuje „zacofanie” znacznej części społeczeństwa, w szczególności grup mniej zamożnych, słabiej wykształconych, bardziej religijnych i mniej ufnych wobec instytucji międzynarodowych, a następie przedstawia postulaty zmiany postaw i mentalności tych grup. Ten sposób ujmowania problemu odnajdziemy w pracach identyfikujących „niekompetencję cywilizacyjną” (Sztompka 1993), „socjalistyczne rezydua” (Marody 1991), „wyuczoną bezradność” (Wnuk-Lipiński 1991), „folwarczne” sposoby zarządzania w organizacjach (Hryniewicz 2007) czy ogólną mentalność homo sovieticus (Świda-Zięba 1994) ${ }^{6}$. Przy czym w ostatnich latach dyskurs „mentalności socjalistycznej” został uzupełniony o dyskurs populizmu, antyeuropejskości, tradycjonalizmu i konserwatyzmu jako zasadniczych hamulców w unowocześnianiu i ,zbliżaniu się do Zachodu" (np. Gorzelak, Jałowiecki 2010).

Z drugiej, dominują diagnozy krytyczne wobec elit liberalnych, które oskarżane są o niedostatek tradycyjnej moralności, patriotyzmu, brak wierności narodowym, religijnym i inteligenckim wartościom bądź sprzyjanie „antyrozwojowym grupom interesu”. Wyrazistym tego przykładem moga być teksty Zdzisława Krasnodębskiego (2003) czy Andrzeja Zybertowicza (2005).

Można powiedzieć, że przedstawiciele obu obozów uprawiają na swój sposób socjologię nie tylko publiczna, ale i „krytyczna”, ale należy zwrócić uwage, że dla większości z nich krytycyzm, w ramach którego operują, jest silnie zdefiniowany przez zasygnalizowane powyżej ramy interpretacyjne. Staje się więc swoistą socjologią krytyczną bez ambicji refleksyjności?

Niemniej jednak, pomimo swej słabości, polskie pole socjologiczne posiada autonomię relatywnie większą od całego szeregu innych subpól pola władzy, na przykład, co szczególnie wyraźne, od subpola medialnego. Autonomia nie jest, co prawda, na tyle silna, aby pole mogło w pełni kontrolować reguły swojego postępowania (oraz dyskursu, który wytwarza) i z tej pozycji formułować niezależne, a więc w pełni naukowe analizy procesów

\footnotetext{
${ }^{6}$ Krytyczną analizę omawianego tu sposobu opisu społeczeństwa polskiego przedstawił Michał Buchowski (Buchowski 2006). Obszerniejszy przegląd tych i podobnych perspektyw można znaleźć w pracy Agnieszki Kolasy-Nowak (Kolasa-Nowak 2010).

7 Socjologia krytyczna jest przede wszystkim socjologia socjologii, tzn. zakłada refleksję nad soba, a zwłaszcza nad społecznymi warunkami, w których powstaje. Kieruje to uwage ku doksie, także „doksie krytycznej”, organizującej myślenia krytycznie nastawionego socjologa. Wątpienie, demistyfikacja musi więc być także demistyfikacją podmiotu demistyfikującego (por. Bourdieu, Wacquant 2001, Wacquant 2004).
} 
społecznych (co jest definicją autonomicznego pola, por. Bourdieu 2001b), ale wystarczająco wyraźna, aby dyskursy, które tam powstaja, odznaczały się znamionami „naukowości” pozwalającymi przysłonić ich aspekt polityczny i uczynić je „obiektywnymi” i ,neutralnymi”. Rzec zatem można, że częściowa autonomia pola socjologicznego jest ze względu na efektywność polityczną komunikatów w nim powstających użyteczna, gdyż ukrywając ich polityczną treść, przekształca je w „neutralne” opisy rzeczywistości. Im bardziej „neutralne”, tym łatwiej przyswajalne, a więc symbolicznie skuteczniejsze w procesie „socjologicznego tworzenia rzeczywistości”.

Zarysowana struktura pola ma rzecz jasna charakter historyczny i jest efektem wcześniejszych walk w polu. Za ich sprawą wykształciła się, jak określiłby to Bourdieu (2001a), specyficzna „przestrzeń możliwości”, czyli symboliczna, słabo uświadamiana rama, strukturująca obecny dyskurs socjologiczny, określająca to, co może być powiedziane (lub nie) i w jaki sposób. Ma więc charakter swoistej cenzury, wykształconej w danej konfiguracji strukturalnej. Kierując się takim założeniem, można powiedzieć, że polska socjologia powojenna, zwłaszcza po roku 1956, rozwijała się pod ogromnym wpływem socjologii amerykańskiej (Sułek 2011). Traktowana była jako obszar „neutralny” (bo ściśle empiryczny), a zatem bardziej „naukowy”, przeciwstawiony wulgarnemu marksizmowi. Podobny podział w polu nauk społecznych miał tylko pozornie charakter dychotomii „heteronomia" (zależność od ówczesnych sił politycznych i explicite wyrażonej ideologii) versus ,autonomia” (neopozytywistyczna socjologia inspirowana myśla amerykańska). W rzeczywistości rzecz kształtowała się już wówczas w kontekście podziału peryferie/centrum, gdzie instytucje tego drugiego, oddziałując przez organizacje w rodzaju Fundacji Forda, zdolne były w niezauważalny sposób narzucić określoną wizję świata ukrytą w samych teoriach socjologicznych. Precyzyjnie rzecz ujmujac, gra ta miała charakter podwójny, geopolityczny i naukowy (przy czym ten ostatni także miał charakter polityczny). Z jednej strony, co jest dość jasne, chodziło o wojnę ideologiczną rozgrywaną w starciu między blokami zachodnim i wschodnim. Z drugiej strony, toczyła się częściowo autonomiczna walka w globalnym polu socjologicznym, w którym stawką było umocnienie pozycji „Triady Kapitolińskiej” - Parsons, Lazerferld, Merton (Bourdieu 2001b). Obie gry częściowo się pokrywały, gdyż naukowcy amerykańscy korzystali ze wsparcia politycznego i ekonomicznego swego kraju (wspomniana Fundacja Forda), przemycając w teoriach socjologicznych określoną ideologię, wizję świata społecznego (przy czym nie musieli czynić tego świadomie) ${ }^{8}$.

8 Analogiczne nakładanie się struktur gry geopolitycznej w Europie Środkowej na wewnątrzamerykańskie rozgrywki w polu akademickim opisali w odniesieniu do nauk ekonomicznych w ostatnich dekadach komunizmu Johanna Bockman i Gil Eyal (Bockman, Eyal, 2002). 
Wystarczy pomyśleć o perspektywie funkcjonalizmu, który trwale zagościł w polskiej socjologii, silnie marginalizując czy wręcz wyrugowując podejścia podkreślające trwałość konfliktów społecznych o charakterze strukturalnym (o ideologicznym uwikłaniu funkcjonalizmu zob. Gouldner 2010, Collins 2009). Na późniejszy kształt polskiej, wyraźnie „niekrytycznej” socjologii, wpływ miały także efekty „lokalne”, na przykład przekonanie wyrosłe ze szczególnie rozumianego marksizmu, iż w społeczeństwie socjalistycznym, z założenia bezklasowym, konflikty klasowe i różnice interesów na tym tle nie mogą się zdarzyć. To wyjaśnia zarówno nieobecność myśli krytycznej jako takiej (np. szkoła frankfurcka pojawia się w polskim dyskursie intelektualnym dość późno i co nie bez znaczenia, najpierw w polu filozoficznym, zob. Bauman i in. 1997), jak i nastawienie na badanie stratyfikacji (w zasadzie bezkonfliktowej), zamiast struktury klasowej (zob. Misztal, Misztal 1984).

Kiedy więc po 1989 roku teorie (neo)modernizacji pozostają jednym z kluczowych aparatów wyjaśniających, a właściwie - jak pokażemy dalej, symbolicznie współtworzących rzeczywistość społeczną - to nie wynikało z ich bezpośredniego i aktualnego importu z obszarów centrum. Grunt dla ponownego odczytania i społecznego wykorzystania tego rodzaju konceptów, w rzeczywistości neutralizujących wszelkie społeczne konflikty (bo widzące je jako przejściowe „patologie” systemu, zob. koncepcję traumy kulturowej P. Sztompki 2000), istniał już dużo wcześniej. Socjologiczna doksa, czyli schematy mentalne powstałe w sytuacji zależności od funkcjonalistycznie bądź pozytywistycznie zorientowanej socjologii amerykańskiej, przez pryzmat której czytano nawet klasyków kontynentalnych (Weber i Durkheim w wersji Parsonsa, a nie w oryginale), naznaczyła polską socjologię także po 1989 roku. Nawet jeżeli tymczasem pojawiły się ujęcia konkurencyjne bądź heretyckie, nie mogły, ze względu na dziedziczony układ całego pola i rozkład sił w nim, podważyć głównych znaturalizowanych kategorii doksycznych, zwłaszcza zorientowania na widzenie konsensusu (a nie konfliktu) i normatywna, ewolucyjna perspektywę rozwoju społecznego, obecną w kolejnych mutacjach (post)nowoczesności (postindustrializmu, społeczeństwa informacyjnego, opartego na wiedzy, sieciowego itd.).

\section{/// Dominujące dyskursy socjologiczne}

\section{a) Niekompetentni przegrani - doksa postępu}

Specyficzna, historyczna konfiguracja polskiego, półperyferyjnego pola władzy oraz równie specyficznie umiejscowionego w nim pola socjologicznego skutkuje łatwościa adaptacji w nim polityczno-medialnej 
doksy. Doksa ta, jako strukturująca „nieświadomość kulturowa” (Bourdieu 1966), w niepostrzeżony sposób angażuje socjologów w proces budowania obecnego ładu społecznego, a przynajmniej jego legitymizacji.

Logika socjologicznych praktyk omawianych wyżej może być zilustrowana licznymi przykładami. My wybraliśmy te reprezentacje, które odnoszą się do kluczowego zagadnienia socjologii, czyli kwestii nierówności społecznych. Podziałem zasadniczym (chociaż oczywiście nie jedynym), który ujawniał się nieustannie w polskiej socjologii ostatnich lat, była dychotomia „wygrani-przegrani” transformacji. Paradygmatyczne dla tego rodzaju wyjaśnień są ustalenia Piotra Sztompki, które, dodajmy, były inspiracją dla kolejnych badań młodszych socjologów ${ }^{9}$. Nie jest to specjalnie zaskakujące, zważywszy na pozycję krakowskiego socjologa - pozostaje on bez żadnej wattpliwości najbardziej rozpoznawalnym w świecie polskim badaczem, co przekłada się bezpośrednio na znaczacy kapitał naukowy w lokalnym (i nie tylko) polu socjologicznym.

A zatem według Sztompki, „wygrani” mają się charakteryzować tzw. kompetencja cywilizacyjna, definiowaną jako „złożony zespół zasad, norm i wartości, nawyków i odruchów [...], których praktyczne i półautomatyczne opanowanie jest warunkiem uczestnictwa w nowoczesnej cywilizacji”" (1993: 88); treścią tych umiejętności ma być między innymi anglosasko rozumiana „kultura rynkowa” (przedsiębiorczość, etos pracy) i „kultura demokratyczna” (aktywność i mobilność jednostki, aktywizm obywatelski itd.). „Przegranym” ma brakować tak rozumianych charakterystyk. Ich porażka, a więc podporządkowana pozycja w strukturze społecznej, wynika rzekomo z odziedziczonych po komunizmie nawykach, definiowanych czasem jako „habitus socjalistyczny” (Sztompka 1995). W podobnym tonie rzecz definiowała Mirosława Marody (1991), utożsamiając ów habitus z solidaryzmem, „ucieczką w kolektywny los”, „oczekiwaniem natychmiastowej gratyfikacji” i innymi domyślnymi zaprzeczeniami wyobrażonej figury zachodniego (protestanckiego) przedsiębiorcy.

Generalnie rzecz biorąc, „przegrani” stanowią inkarnację homo sovieticus (Sztompka 1993). Inni, młodsi badacze uzupełnili te charakterystyki badaniami empirycznymi. I tak Wojciech Broszkiewicz (2010) badał kapitał kulturowy młodzieży na Podkarpaciu, usiłując dociec, czy młodzi maja wystarczająca „kompetencję cywilizacyjną” (w rozumieniu Sztompki), aby

\footnotetext{
9 Idąc za Bourdieu (1984), nie traktujemy analizowanych podmiotów jako realnych postaci - „jednostek empirycznych”. Raczej są one dla nas ,jednostkami epistemicznymi”, złożonymi z cech charakterystycznych dla pozycji w polu, które zajmują. Przez ich praktyki unaocznić chcemy więc logikę działania pola socjologicznego, a nie pojedynczych socjologów.
} 
urzeczywistnić ideał „społeczeństwa informacyjnego”. Wcześniej Adam Bartoszek (2003) próbował określić poziom „kapitału społeczno-kulturowego" młodej inteligencji. W obu wypadkach wartość kapitału nie jest, jak u Bourdieu, przedmiotem walk społecznych, ale zostaje wydedukowana z zakreślonego punktu docelowego, oczekiwanego społecznego postępu - w pierwszym wypadku „społeczeństwa opartego na wiedzy”, w drugim, anglosasko rozumianej gospodarki rynkowej. Znaczące jest, że w obu wypadkach, pomimo wprost formułowanych odniesień do Bourdieu, odczytanie jego koncepcji ma charakter wybitnie niekonfliktowy; nie ma więc raczej mowy o przemocy, dominacji i władzy, jest za to język „mobilności”, „dystansów” i „kompetencji osobowych”.

Szczególnie uderzające w powyższych charakterystykach jest posługiwanie się prostym schematem ewolucyjnym, który stanowi dziś polityczną i dziennikarską doksę, dobrze widzianą w postaci wszelkich dyskursów „modernizacji” czy też „europeizacji”, których strukturalnego źródła można upatrywać w peryferyjnym położeniu Polski. Dawne teorie modernizacji przekształciły się więc w wiedzę zdroworozsądkową, prawdziwy sens commun, którym, co najbardziej zaskakuje, posługują się dziś (niektórzy) socjologowie.

Już w tym wątku widać silne zazębienie się pól medialnych i politycznych z polem socjologicznym, a nawet pewnego rodzaju niedostrzeżone podporządkowanie nauki przez przejęcie mentalnych struktur medialno-politycznego „zdrowego rozsądku” zasadzającego się na neoliberalnych, dominujących założeniach: „roszczeniowość” „lenistwo” i brak aktywności homo sovieticus jako dziedzictwo przemijającego, ale ciagle obecnego „mentalnego komunizmu” przeciwstawione oczekiwanej figurze przedsiębiorczego, zwesternizowanego kosmopolity, najlepiej zaś self-made-mana. Jednocześnie w „doksie postępu” zawarte jest milczące hierarchizowanie, określające niekwestionowaną wyższość tego, co w wyobrażeniu zachodnie. Odnajdziemy tu całą serię wzajemnie nakładających się znaturalizowanych dychotomii: USA, Europa Zachodnia/Europa Środkowa i Wschodnia, wyższe/niższe, postępowe/zacofane, przyszłość/przeszłość, kapitalizm/ socjalizm, wolny rynek/etatyzm, rozum/emocje, a nawet kultura/natura.

Ważne jest, że taki doksyczny, samo-przez-się zrozumiały schemat w ukryty sposób legitymizuje istniejące nierówności. Bourdieu twierdzi, iż ,,$\ldots]$ stosowanie ewolucjonistycznego schematu [...] pozwala dominującym postrzegać swój sposób bycia lub postępowania jako urzeczywistniony wymóg swojej egzystencji [...]" (2005a: 473). Poprzez narzucenie arbitralnego, ale widzianego jako uniwersalny, schematu ewolucyjnego, 
uniwersalizacji ulega wszystko to, co jest z nim zgodne. Odrzuca się zaś to, co doń nie pasuje (nawet jeżeli są to całe kategorie populacji).

Drugim elementem jest wyraźne skrzywienie mentalistyczne, a nawet psychologiczne. Opisani socjolodzy przez zapoznanie społecznych warunków wytwarzania określonych dyspozycji (np. wspomnianego habitusu) tworzą wrażenie cech osobowościowych, niemal wrodzonych, owych „przegranych”. Podobny tryb ujmowania procesów społecznych oraz przyczyn nierówności jest, po raz kolejny, całkowicie zgodny z „dziennikarska wizją świata" (Bourdieu 2011) oraz dominująca w przestrzeni medialnej (w jej podstawowych zakresach) ideologii neoliberalnej. Zarówno wizja dziennikarska (która odpowiada habitusowi klasy średniej, por. Bourdieu 2005a), jak i wizja neoliberalna redukują rzeczywistość do sumy indywidualnych i w pełni świadomych wyborów. Wszelkie błędy w tym zakresie, na przykład podjęcie decyzji skutkujących ubóstwem, są co najwyżej kwestią niewłaściwej, „dysfunkcjonalnej” mentalności, której symbolem może być „kultura ubóstwa” (krytycznie na ten temat: Lamont, Small 2008) ${ }^{10}$.

Łatwość posługiwania się taką zindywidualizowaną, „świadomościową" perspektywą wynika z opisanego wcześniej, ale społecznie zapoznanego dziedzictwa całego pola. Amerykańska socjologia sondażowa zostawiała swój trwały ślad nie tylko w dominacji określonej metodologii, ale także specyficznej ontologii. Jeżeli bowiem, jak twierdzi Izabella Bukraba-Rylska (2004: 158), dominacja sondaży prowadzi do tego, że „,[...] badanie rzeczywistości społecznej zmienia się w badanie świadomości respondentów [...]”, to rzeczywistość społeczna zaczyna być sprowadzana do sumy zindywidualizowanych subiektywności, zbioru samoświadomych jednostek $^{11}$. W konsekwencji czego następuje odejście od wyjaśnień strukturalistycznych na rzecz indywidualistycznych (mentalnych, kulturowych),

${ }^{10}$ Kiedy mowa jest o „habitusie socjalistycznym” i konieczności jego mentalnej zmiany w kierunku postaw bardziej prorynkowych, zapomina się, że, jak pokazuje sam Bourdieu, „[...] poniżej pewnego poziomu bezpieczeństwa ekonomicznego, zapewnianego przez stabilne zatrudnienie oraz określony minimalny i stały dochód, podmioty ekonomiczne nie są w stanie ani obmyślić, ani zrealizować większości działań, które opierają się na wysiłku uchwycenia przyszłości, takich jak wykalkulowane zarządzanie zasobami w czasie, wzięcie kredytu bądź kontrolę płodności” (Bourdieu 2000: 28).

${ }^{11}$ Paradoksem jest, iż nastawienie mentalistyczne i „świadomościowe” niektórych socjologów łączy się ściśle z ignorowaniem samej podmiotowości społeczeństwa, a nawet wyraźnym wartościowaniem badanych poglądów czy opinii. Bukraba-Rylska pisze: „Niezależnie [...] od tego, że socjologowie dysponują w zasadzie tylko opiniami badanych na temat rzeczywistości, nie wahają się przed kwalifikowaniem ich jako słusznych bądź też fałszywych, tak jakby byli w posiadaniu także prawdy o tej rzeczywistości, choć nie bardzo wiadomo, w jaki sposób stała się ona im dostępna” (Bukraba-Rylska 2004: 158). 
co z kolei znajduje efekt w naturalizacji istniejącego ładu. Mówiąc inaczej, socjolodzy, narzucając pozornie naukowe wyjaśnienie, będące w istocie nieznacznie przetworzona wersja zdroworozsądkowych (i przez to dominujących) poglądów, przyczyniają się do tworzenia, jak to określa Bourdieu (1996), socjodycei, które na podobieństwo społecznych teodycei, opisanych przez Webera (1995), legitymizują zarówno pozycje „przegranych” („teodycea nieszczęścia”), jak i „wygranych” („teodycea przywileju”).

\section{b) Zastużona wygrana}

Podobne współtworzenie socjodycei wyraźnie widać w naukowych oraz medialnych wypowiedziach innego polskiego socjologa, Henryka Domańskiego. Analizując strukturę społeczna polskiego społeczeństwa i opierając swoje wnioski na dobrze ugruntowanym materiale empirycznym, łatwo i niepostrzeżenie przechodzi od opisu i wyjaśnienia do naukowego uzasadnienia nierówności. A zatem zapośredniczony i ukrywany przez system szkolny transfer kapitału kulturowego w uprzywilejowanych rodzinach klas średnich i będące jego konsekwencją dopasowanie poziomu wykształcenia do uzyskiwanych dochodów ma sygnalizować wzrost merytokracji „[...] czyli wynagradzania za osobiste 'zasługi', jeżeli przyjąć - co czynimy za większością autorów - że wyższe wykształcenie znaczy odpowiednio wyższe 'zasługi' (czyli ang. merits), obejmujące zdolności, talent, kwalifikacje zawodowe i inne nakłady" jednostek (Domański i in. 2005: 20-21). Jeszcze dosadniej zostało to ujęte w wywiadzie prasowym: „Nierówności są wbudowane w każdy system i - co gorsza dla tych, którzy są na dole - one są funkcjonalne dla systemu. To znaczy, że nierówności muszą być, aby stosunki, więzi i relacje między ludźmi były stabilne. Nierówności są konieczne dla zapewnienia porządku i ładu, a w systemach rynkowych stanowia jeden z czynników motywujących do wysiłku, kształcenia się i efektywnej pracy. Hierarchia społeczna tkwi u podstaw ideologii społeczeństwa amerykańskiego, które - jak dotąd - funkcjonuje całkiem nieźle. [...] Ten porządek jest [...] niezbędny, aby społeczeństwo się rozwijało i było stabilne. Zawsze część ludzi będzie na szczycie, a część - na dole" (Pilawski 2011) (podkr. T.W.\&T.Z.).

Za pozornie obiektywną analizą stoją tu z gruntu ideologiczne założenia, kluczowe, dodajmy, dla porządku neoliberalnego, co po raz kolejny pokazuje (zapewne nieświadoma) zależność od politycznej i medialnej doksy. Naukowe legitymizowanie istniejącego ładu poprzez twierdzenia, że teraz wreszcie mamy do czynienia z porządkiem merytokratycznym, może mieć miejsce wyłącznie przy zignorowaniu faktu, że zajęcie określonej 
pozycji, poświadczonej tytułem szkolnym (a dalej odpowiednim wynagrodzeniem za pracę), nie tyle jest kwestią indywidualnego wysiłku, ile odziedziczonego w rodzinie kapitału, przede wszystkim kulturowego (Bourdieu 1996; Bourdieu, Passeron 2006). Nawet jeżeli w innym miejscu Domański wspomina o tych zasobach (Domański, Tomescu-Dubrow 2008), to nadal, nie wyjaśniając ich strukturalnego efektu, akcentując wymiar indywidualny, w rezultacie legitymizuje naukowo istniejący układ. Dobitnie ujmuje to w wypowiedzi prasowej:

Wspólną cechą tej kategorii - ludzi wykluczonych, lub czujących się takimi, i przekonanych, że są dotknięci złym losem - jest słaba pozycja rynkowa. Nie maja „kapitału edukacyjnego” i kulturowego, który pozwoliłby im na podjęcie wysiłku, więc szukają wsparcia u państwa, w instytucjach opieki społecznej czy „kogoś” zajmującego się rozwiązywaniem problemów. Wielu z nich wybiera taką „prosocjalną”" strategię, bo jest łatwiejsza. Dla nich to jest łatwiejsze, żeby polegać na innych. (Wąsowski 2012)

W konsekwencji pozostaja oni „ofiarami losu”: „To trafne, aczkolwiek skrótowe określenie. I nawet nie jest obraźliwe. Oni po prostu nie potrafia sobie radzić z losem, stawić czoło przeciwnościom"(ibidem).

Sztandarowa koncepcja Bourdieu - kapitał kulturowy - jest u Domańskiego rozumiana, w sensie typowo ekonomicznym, jako zasób indywidualny, czyli raczej jako „kapitał ludzki” (na temat różnic w tym zakresie: Warczok 2010). To, co jest tu pomijane, a co stanowi o istocie teorii reprodukcji Bourdieu, to nie tyle kwestia koncentracji zasobów (kapitałów - ekonomicznego i kulturowego) w górnych i średnich rejonach przestrzeni społecznej, ile fakt, że system szkolny dokonuje niemal magicznej przemiany, „transsubstancjacji” odziedziczonego w rodzinie kapitału kulturowego w szkolne oceny, które oficjalnie nie oceniaja przecież nierówności tego dziedziczonego zasobu (lecz wysiłki, starania, pracowitość oraz „talent” i „zdolności” ucznia). Dzięki szkole dziedziczony kapitał przestaje być kapitałem, a staje się talentem, darem lub wyrazem pracowitości; to, co społeczne, staje się „osobowe”, zarówno dla „zwycięzców”, jak i „przegranych”.

Podobne dyskursy przyjmowane są łatwo w polu medialnym, gdyż stoją za nimi dokładnie te same doksyczne założenia. „Zwycięzcy” w społecznej grze maja odpowiednie cechy wrodzone (talent) lub/i angażują się w ponadprzeciętny wysiłek (edukacja). „Przegrani” są sami sobie winni, gdyż albo takich unikalnych cech nie maja, albo są po prostu leniwi. W tym miejscu także obecna jest „doksa postępu”, niewypowiedziany 
wprost schemat ewolucyjny, ze Stanami Zjednoczonymi widzianymi jako pożądany punkt końcowy procesu transformacji społeczeństwa. Całość zaś oparta jest na założeniach naiwnego i wielokrotnie krytykowanego funkcjonalizmu. W trybie charakterystycznym dla tego nurtu Domański, nie pytając, komu służą owe „funkcje społeczne”, dokonuje niewypowiedzianej legitymizacji nierówności (funkcje mają służyć systemowi jako takiemu). W efekcie bezrefleksyjnie przyjmowany neoliberalizm łączy się doskonale z podstawowymi założeniami strukturalnego funkcjonalizmu oraz ewolucjonizmu teorii modernizacji ${ }^{12}$.

Zatem wspomniani socjologowie, arbitralnie zakładając, czego „społeczeństwo potrzebuje” (jakie spełnia funkcje) i dokąd zmierza („,modernizuje się" zgodnie ze wzorcem zachodnim), wyrażaja po prostu, najprawdopodobniej nieświadomie, głos dominujących. Za ich sądami stoi określona doksa, a ta z zasady stanowi „zdrowy rozsądek” tych, którzy zajmuja pozycje zwierzchnie.

Opisane dyskursy i doksyczne klasyfikacje narzucane przez socjologów moga być rozpatrywane jako „praca symboliczna”, której paradoksalnym efektem jest przekształcenie istniejącej, nierównej struktury kapitałów w przestrzeni społecznej w kapitał symboliczny, czyli kapitał uprawomocniony. Dzieje się to, kiedy zaczyna być on postrzegany (a dalej cała struktura społeczna) za pomoca specyficznych kategorii uprawomocniających, które zamieniają to, co partykularne, w uniwersalne. Nie jest bowiem tak, że hierarchie społeczne tworzą się jedynie przez nierówność w dostępie do określonych dóbr. Równie ważny, oprócz rzeczonego wymiaru „materialnego”, jest wymiar „symboliczny”, a więc prawomocna definicja owych dóbr (którymi, dodajmy, moga być najbardziej pospolite właściwości) (por. Bourdieu 2008) ${ }^{13}$.

Narzucenie prawomocnych klasyfikacji, czyli realizacja przemocy symbolicznej w sensie ścisłym, jest dokładnie tym, co czynią opisani wyżej socjologowie. Zamiast dociekań istoty tak rozumianej „uprawomacniajacej pracy symbolicznej", dokładnie taka pracę wykonuja. Pod pozorem

\footnotetext{
${ }^{12}$ Nie jest bez znaczenia, że funkcjonalizm strukturalny ujmowany był już przez amerykańskich krytyków jako nurt szczególnie konserwatywny, skierowany na społeczne uzasadnienia status quo (por. Collins 2010; Gouldner 2010).

${ }^{13}$ Męskość jako charakterystyka „lepsza”, „wartościowsza” od kobiecości, „szlachectwo” przeciwstawione „pospolitości”, inteligencja (mierzona testami IQ) oddzielająca „mądrych” od „głupich” czy też szczególna „wrażliwość” pozwalająca odróżnić ludzi „posiadających gust” od tych, którzy hołduja „bezguściu” - wszystko to stawki w grze, klasyfikacje, za sprawą których nierówność, z gruntu arbitralna, staje się obiektywna i naturalna - zostaje wpisana w porządek rzeczy.
} 
neutralnej analizy narzucaja klasyfikacje i wyjaśnienia, które w magiczny niemal sposób przekształcają nierówności w różnice naturalne, a co za tym idzie, w niewypowiedziany sposób społecznie uzasadnione. Uzasadnieniem mogą być „funkcjonalne wymogi systemu” lub też teleologicznie widziany „postęp” (lub też „modernizacja”) ${ }^{14}$.

Zapoznany efekt podobnej legitymizacji jest możliwy dzięki opisanemu strukturalnemu położeniu pola socjologicznego w polu władzy. Mimo jego słabej autonomii znajduje się ono w pewnym dystansie wobec sił ekonomicznych i politycznych. Dystans ten jest kluczowy, gdyż zwiększa skuteczność symboliczna. Bourdieu (2006: 149) pisze: „[...] władza, której podstawa jest (fizyczna lub gospodarcza) siła, może ulec uprawomocnieniu tylko przez władzę, której nie można podejrzewać o posłuszeństwo sile". Opisani socjologowie dokonują aktu legitymizacji z pozycji i pod pozorem nauki, nie może więc dziwić, że pozostaje on nierozpoznany, a przez to efektywny ${ }^{15}$. Co ważne jednak, opisane symbolizacje, dyskursy powstające na bazie doksy, która uzasadnia status quo, nie są przypadkowe. Wynikają ze strukturalnego położenia wspomnianych socjologów. Zajmują oni pozycje dominujące w polu, które inaczej niż w krajach zachodnich nie lokuje się na pozycjach podporządkowanych wobec pola ekonomicznego. Jak powiedzieliśmy, inteligencja jest kategoria panującą w warunkach półperyferyjnych, co oznacza, że generalne pole kulturowe ma status dominujący, ponieważ „obsługuje” kapitał globalny (a nie jest w sporze z lokalnym kapitałem ekonomicznym, ponieważ akumulacja tego ostatniego była historycznie i strukturalnie bardzo ograniczona). A zatem inteligencja, w szczególności jej procentrowa frakcja, nie będąc w pozycji zdominowanej, nie ma, jak pola kulturowe w krajach centrum, „naturalnej” niejako inklinacji do krytyki. Zamiast tego, zgodnie ze swoją dominująca pozycja, będzie dyskursywnie uzasadniać status quo.

Wszelako zarówno szersze pole kultury, jak i zawierające się w nim pole socjologiczne, nie sa monolitem, ale obszarem gry, co oznacza, że także w nich znajdą się podporządkowani, którzy status quo będa

\footnotetext{
${ }^{14}$ Można tu mówić za Bourdieu (1989) o swoistym „efekcie teorii”, czyli takiej sytuacji, kiedy teoria naukowa nie tyle opisuje dany stan rzeczy, ile określa, jak rzeczywistość i jej podstawowe podziały winny wyglądać.

${ }^{15}$ Co ważne, dystans między przestrzeniami (polem ekonomicznym i politycznym a naukowym) warunkuje dystans językowy. W polu socjologicznym poszczególne zjawiska muszą być opisane w języku socjologicznym. Podobna „cenzura pola” (Bourdieu 1991b) umożliwia przedstawienie treści spoza pola w pozornie neutralnej formie naukowej, czyli obiektywnej. W tym sensie na przykład interes dominujących przekształca się, dzięki językowi funkcjonalizmu, w „funkcjonalne wymogi systemu”.
} 
kwestionować. Funkcjonują oni jednak w kategoriach istniejącego układu sił i sporu miedzy siłami pro- $i$ antycentrowymi.

\section{/// Krytyka heretycka}

W odpowiedzi na ortodoksję procentrowej modernizacji pojawiają się stanowiska przeciwstawne, kwestionujące tak wyznaczoną ścieżkę rozwojową i uzasadnienie istniejących podziałów i hierarchii. Homologicznie do pola politycznego najbardziej wyraziste w polu socjologicznym sa głosy sceptyczne wobec zachodniego rdzenia (centrum), a precyzyjnie rzecz ujmując, zgodnie z logika pola, stanowiska przeciwstawne wobec sił nastawionych procentrowo. Ostrze krytyki wymierzone jest więc w planie szerszym (całości pola władzy) w tych teoretyków, publicystów i polityków, którzy sprzyjają wizji bezrefleksyjnego, jak to się ujmuje, podążania za centrum (za Zachodem, Europa), w planie węższym (w samym polu socjologicznym) w badaczy społecznych podobnie zorientowanych. Jednak w wypadku tego ostatniego dyskurs będzie nieco inny, dostosowany do reguł samego pola. Może więc sublimować się w czysty spór teoretyczny.

Spośród badaczy sytuujących się po stronie heretyckiej kluczowe pozycje, ze względu na posiadany kapitał naukowy, będa zajmować Andrzej Zybertowicz, Zdzisław Krasnodębski i Jadwiga Staniszkis. Podobnie jak w wypadku ortodoksji, tak i „konserwatywni” krytycy z przeciwstawnej strony pola próbuja narzucić określona siatkę klasyfikacji społecznych. Ze względu na fakt zajmowania pozycji relatywnie zdominowanej w polu będą to klasyfikacje heretyckie, podważające status quo i odwrotne w stosunku do klasyfikacji prawomocnych - ortodoksyjnych. Dominujący w nowym ładzie zwycięzcy transformacji są tutaj denuncjowani; w wersjach ostrzejszych (raczej publicystycznych) oskarżani wręcz o narodową zdradę, w wersjach bardziej subtelnych postrzegani jako „dziedzice” poprzedniego ustroju. Do dyskursu tego rodzaju można zaliczyć liczne rozważania na temat „kapitalizmu politycznego” (Staniszkis 2006) bądź słynnego „układu”. „Dziedzic” poprzedniego ustroju nie jest w tym wypadku przegranym bomo sovietucus, ale cynicznym aparatczykiem lub byłym funkcjonariuszem SB (Loś, Zybertowicz 2000).

Jako że pole socjologiczne jest relatywnie odseparowane od pozostałych pól (zwłaszcza politycznego), spory czysto polityczne przyjmuja nierzadko, zgodnie z cenzura pola naukowego, naukowa - socjologiczną - formę. Otwarte spory polityczne można toczyć w polu medialnym, kiedy socjolog występuje w roli publicysty. Występując jednak w samym polu socjologicznym, musi dokonać swoistej transformacji języka, 
podporządkować go regułom naukowości, przedstawić w kategoriach socjologicznych. Ale w żadnym wypadku nie zmienia to logiki walki. Komponent polityczny ulega ukryciu i przez to, można powiedzieć, staje się bardziej efektywny. Znaczące jest to, że o ile część ortodoksyjna posługuje się teoria bezkonfliktową (funkcjonalizm bądź jego pochodne), o tyle strona heretycka aspekt konfliktu w życiu społecznym właśnie podkreśla. Jest to całkowicie zgodne $z$ heretyckim, zdominowanym usytuowaniem w polu. Jeżeli ortodoksi, bez względu na pole, w którym działaja, będą podkreślać aspekty apolityczne, wartość negocjacji, dialogu, symetrii, równowagi oraz niezaangażowania (Bourdieu 1991a), to heretycy wręcz przeciwnie, akcentować będa hierarchie, konflikt i niesprawiedliwe, jak to przedstawiaja, podziały. Nie może więc dziwić użycie teorii konfliktowej przez socjologicznych heretyków ${ }^{16}$. Heretycy sytuuja się jednocześnie na pozycji rzeczników zdominowanych, co wynika z układu strukturalnego. Ulokowani na zdominowanych pozycjach w polu władzy znajduja naturalne niejako porozumienie ze zdominowanymi w szerszym polu społecznym. Nie jest więc przypadkowe, że Zybertowicz pojawia się często w Radiu Maryja, uznanym, jak wiadomo, za głos przegranych i zdominowanych - „moherowych beretów”.

Wyrazistym przykładem sporu socjologicznego z tłem ściśle politycznym była publiczna dyskusja Andrzeja Zybertowicza i Piotra Sztompki podczas jednej z sesji plenarnych Ogólnopolskiego Zjazdu Socjologicznego w Krakowie w 2010 roku (Sztompka 2011, Zybertowicz 2010). Później spór ten, który w istocie był sporem dwóch obozów pola socjologicznego, przeniósł się nawet na łamy prasy (wystąpienia obu polemistów z forum zjazdu ukazały się w znanych gazetach codziennych). Sztompka optował za „socjologia globalną, ogólnoświatową wspólnotą socjologów, która w nieskrępowany sposób kumuluje wiedzę i rozwija w zbiorowym, koncyliacyjnym wysiłku teorię socjologiczna. Zybertowicz przeciwstawił się temu, twierdząc, że socjologia lokalna winna służyć przede wszystkim interesom narodowym. I tak dwie generalne wizje socjologii stanowią inna odsłonę politycznego sporu - procentrowej, dążącej do modernizacji ortodoksji, i herezji, postrzegającej poważne przeszkody w tym procesie, a nawet optującej za budowaniem kontrsiły wobec presji centrum.

Stanowisko heretyków ma w sobie pewien potencjał krytyczny, demistyfikujący istniejące relacje władzy. Jednakowoż krytyka ma dość wąski zakres. Ogranicza się do wskazania zagrożeń dla całego państwa.

${ }^{16}$ Zauważmy, że podobna sytuacja miała miejsce w szerszym, globalnym polu socjologicznym. Odpowiedzią na dominujący w latach 50. i jeszcze częściowo 60. funkcjonalizm Parsonsa i Mertona była m.in. teoria konfliktu R. Dahrendorfa czy R. Collinsa. 
Zybertowicz (2006) w taki oto sposób adaptuje pojęcie przemocy symbolicznej Bourdieu: „Czy pracuja grupy ekspertów systematycznie określajacych strefy naszej realnej podmiotowości w grze europejskiej i globalnej - w warunkach suwerenności rozproszonej? Czy ktoś precyzyjnie identyfikuje zakres tzw. przemocy symbolicznej wytwarzanej przez międzynarodowe korporacje, promujące w Polsce kulturę konsumpcyjną i kosmopolityczny system wartości?’. Co znamienne, nie wskazuje się w tym wypadku na podziały wewnętrzne (np. klasowe) z wyjątkiem ,antyrozwojowych grup interesu" (Zybertowicz 2005), których usunięcie miałoby, jak można z tego wywnioskować, umożliwić „prawdziwy i nieskrępowany rozwój”. Można więc powiedzieć, że krytyka tego typu, szukająca makiawelicznej grupy, która odpowiada za społeczne zło, to „funkcjonalizm najgorszego”, który nie dostrzega, że: „[...] mechanizmy społeczne nie są efektem makiawelicznej intencji. Są one znacznie bardziej inteligentne niż najbardziej inteligentne podmioty dominujące” (Bourdieu 1993a: 71). W efekcie podobnych poszukiwań herezja, miast szerszej krytyki, tworzy nowa prawicowa socjodyceę, tłumaczącą społeczne zło przez aktywność określonej grupy ludzi. Ignorując strukturalne przyczyny nierówności, socjodycea taka niepostrzeżenie legitymizuje neoliberalną doksę. Sugeruje bowiem, że ,anty-rozwojowe grupy interesu” przeszkadzają w rozwoju wolnego rynku. Jeżeli więc heretycy posługuja się teorią krytyczna, jest to krytyka w najlepszym razie jedynie częściowa.

\section{/// Podsumowanie}

Lokalne pole władzy, a wraz z nim polskie pole socjologiczne przyjmuje strukturę dychotomiczna, wprowadzająca zasadniczy podział na stanowiska pro- i antycentrowe (lub sceptyczne wobec centrum). Nie oznacza to oczywiście, że wszystkie idee i teorie powstające w polu socjologicznym dopasowują się automatycznie do tak widzianego podziału. Można wskazać przecież pozycje otwarcie krytyczne (por. np. Gdula, Sadura 2012) ${ }^{17}$.

\footnotetext{
${ }^{17}$ Autorzy niniejszego tekstu, hołdując zasadzie socjologii refleksyjnej i analizując strategie innych badaczy, nie moga uciec od auto-analizy - a raczej auto-socjo-analizy. Sytuujemy się zatem raczej na pozycjach strukturalnie zdominowanych w polu, jednak ze względu na brak realnych powiązań politycznych i oddalenie od pola medialnego pozostajemy relatywnie odseparowani od symbolicznej dychotomii pro-centrum/centro-sceptyzm. Najbliższa jest nam, co nie powinno być żadnym zaskoczeniem, socjologia krytyczna, która w zarysowanym układzie sytuowałaby się pośrodku przywołanego podziału strukturalnego, czyli w miejscu raczej niepewnym, bo dopiero wykuwanym. Nasze relatywnie nieuwikłanie w dominujący podział wynika także z faktu, iż nie jesteśmy trwale związani z żadną lokalną
} 
Niemniej jednak siła ciążenia dwubiegunowej struktury spycha takie reprezentacje bądź w jedną, bądź w drugą stronę („rozbrajając” tym samym ich krytyczny potencjał). Szczególnie dobrze jest to widoczne w dominujących, najbardziej publicznie widzialnych rejonach pola. Tam właśnie logika pro- i antycentrowa oddziałuje najsilniej, ponieważ jest sprzęgnięta z dominująca strukturacja pól politycznych i medialnych.

Rzecz jasna, zarysowana struktura jest społeczną konstrukcją, wynikiem poprzednich walk społecznych i w samej walce może zostać zmieniona. Jest to jednak trudne, gdyż nie ogranicza się do stanu sił lokalnych, czy to naukowych, czy politycznych, ale stanowi efekt generalnego ulokowania naszego kraju w systemie światowym. Sama półperyferyjna pozycja strukturyzuje lokalne pola władzy, unieważniając, bądź przesuwając na drugi plan, to, co stanowi o istocie pól władzy w centrum, czyli podział między kapitałem ekonomicznym i kulturowym (czego inkarnacja jest konflikt między bourgeois a artysta), między siła pieniądza a siłą kultury, kiedyś zaś władzą doczesną a władzą duchową, dziś między prawica a lewica. Miejsce tego sporu zajął konflikt „modernizatorów” z „tradycjonalistami” (Bourdieu 2005b), a inne społeczne zmagania czytane są przez tę właśnie siatkę znaczeń. Z uwagi na brak lokalnej burżuazji i znaczącej lokalnej akumulacji kapitału ekonomicznego, to, co materialne, zostaje zapoznane, a kluczowy staje się konflikt kulturowy - posiadanie lub nie odpowiednich „kompetencji cywilizacyjnych” lub też „mentalności”, dzięki której można będzie „dogonić Zachód” lub tė̇, z drugiej strony, bronić tradycyjnych, lokalnych „wartości”. Inteligencja jako grupa dominująca znakomicie odnajduje się w tego rodzaju zmaganiach. Socjolodzy zaś, jako modelowi inteligenci, angażują się w tak ustawioną grę, próbując bądź rozpoznać najbardziej sprzyjające warunki i dyspozycje indywidualne „modernizacji”, bądź denuncjować (często personalnie) tych, którzy mają stanowić zagrożenie dla kraju i jego tradycyjnych wartości, pomijając równocześnie realne, choć ukryte siły stanowiące o istocie zależności.

Hegemonia obozu „procentrowego" naturalizuje się, przestaje być ideologia, staje się stanowiskiem „rozsądnym”, ponieważ ustawia się dokładnie na pozycji centralnej, to znaczy poza lewicą i prawica. Procentrowość, a więc stanowisko promodernizacyjne, jest „miejscem neutralnym” (por. Bourdieu, Boltanski 1976), bo ulokowanym na osi czasowej,

„szkołą” bądź „ośrodkiem”. Oczywiście, korzystając z teorii Bourdieu, wypracowanej przecież w obszarze centrum, jesteśmy od niej symbolicznie zależni, jednak staramy się koncept francuskiego socjologa przepracowywać przez samo doświadczenie (pół)peryferii. Zgodnie więc z zasadą, do której sam Bourdieu zachęcał, jesteśmy „z i przeciw” Bourdieu. 
znamionującym „przyszłość” przeciwstawiona „przeszłości”. I to do „przeszłości” właśnie zostaje odesłana zarówno prawica (konserwatywna, „przestarzała”), jak i lewica (komunistyczna bądź reprezentująca „przestarzałe” państwo opiekuńcze, które „zbankrutowało”). „Przyszłościowa” procentralność, „nowoczesność”, jest więc uniwersalna i uniwersalizująca wobec przekroczonych przez nią z gruntu partykularnych i ,anachronicznych" opcji prawicowych i lewicowych. Dzięki temu jest zdolna przejąć sam dyskurs krytyczny, a tym samym pozbawić go realnego społecznego potencjału demaskatorskiego. Zarysowane powyżej sposoby użycia w Polsce tak znaczących dla słownika krytycznego terminów, jak kapitał kulturowy czy habitus (w wersji habitusu socjalistycznego), jest wystarczająco wymowne. Przy czym owe „pobożnie obłudne odniesienia do uniwersalności” (Bourdieu 2005b: x), jest całkowicie zrozumiałe, jeżeli uwzględni się pozycję procentrowych modernizatorów. Wysunięci na pozycje dominujące w lokalnym polu władzy nie mogą nie mieć partykularnego interesu w utożsamieniu z samym centrum, bo dzięki temu ich interes nabywa cech uniwersalnych, a zajmowana pozycja zostaje uprawomocniona.

Z drugiej strony, kiedy obóz antycentrowy sięga po język krytyczny, adaptuje go do swoich wąsko rozumianych interesów „narodowych”, skupionych na wymiarze kulturowym i politycznym a ignorującym zależności ekonomiczne, co też go w znaczący sposób rozbraja.

Główną zatem przeszkodą w rozwoju myśli krytycznej i realnie krytycznego zaangażowania się polskich socjologów wydaje się przede wszystkim ograniczona neutralność pola socjologicznego. W warunkach półperyferyjnych, za sprawą braku silnych instytucji państwowych, które mogłyby stanowić swoiste medium między polami, wchodzi ono w logikę pól politycznych, medialnych oraz ekonomicznych. Nie ma koniecznej przestrzeni, aby zneutralizować i poddać refleksji ich doksę, zamiast tego samo działa podług jej niezauważalnych struktur.

Wraz z odesłaniem w przeszłość opozycji prawica-lewica dylematy autonomii i heteronomii zostają unieważnione lub przekształcone w opozycję między zależnością a deklarowaną niezależnością wobec centrum. Nawet jeżeli teoria krytyczna jest uprawiana, to z daleka od głównego dychotomicznie ustawionego pro- lub antycentrowego nurtu. Stoi więc stale przed dylematem: zaangażować się po którejś z wymienionych stron lub skazać na całkowite niemal zmarginalizowanie. 
Bibliografia:

/// Alexander J. 2010. Znaczenia społeczne. Studia z socjologii kulturowej, tłum. S. Burdziej, J. Gądecki, Nomos, Kraków.

/// Bajer M. 2013. Rody uczone. Kreski do sækicu, Wyd. UMK, Toruń.

/// Bartoszek A. 2003. Kapitat spotecæno-kulturowy młodej inteligencji wobec wymogón rynku, Wydawnictwo UŚ, Katowice.

/// Bauman Z., Kubicki R., Zeidler-Janiszewska A. 1997. Humanista w ponowoczesnym świecie: rozmony o sztuce sycia, nauce, syciu sztuki i innych sprawach, Zysk i s-ka, Poznań.

/// Bockman J.K., Eyal G. 2002. Eastern Europe as a laboratory for economic knowledge: The transnational roots of neoliberalism. „American Journal of Sociology" 2002, 108, s. 310-352.

// / Bourdieu P. 1966. Champ intellectuel et projet créateur, „Temps modernes” 1966, nr 246, s. 865-906.

/// Bourdieu P. 1984. Homo academicus, Édition de Minuit, Paris.

/// Bourdieu P. 1988. Vive la Crise! For heterodoxy in social science, „Theory and Society" 1988, 17, s. 773-787.

/// Bourdieu P. 1989. Social Space and Symbolic Power, „Sociological Theory" 1989, vol. 7, nr 1, s. 14-25.

/// Bourdieu P. 1991a. Language and Symbolic Power, Polity, Cambridge.

/// Bourdieu P. 1991b. The Political Ontology of Martin Heidegger, Stanford University Press, Stanford.

/// Bourdieu P. 1993a. Sociology in Question, Sage, London-Thousand Oaks-New Dehli.

/// Bourdieu P. 1993b. The Field of Cultural Production, Polity, Cambridge.

/// Bourdieu P. 1996. The State Nobility. Elite School in the Field of Power, Stanford University Press, Stanford.

/// Bourdieu P. 2000. Making the economic habitus. Algerians workers revisited, „Ethnography” 2000, vol. 1(1), s. 17-41.

/// Bourdieu P. 2001a. Reguly sztuki. Geneza i struktura pola literackiego, tłum. A. Zawadzki, Universitas, Kraków.

/// Bourdieu P. 2001b. Science de la science et réflexivité, Raisons d'agir, Paris.

/// Bourdieu P. 2005a. Dystynkija. Spoteczna krytyka władzy sadzenia, tłum. P. Biłos, Wydawnictwo Naukowe PWN, Warszawa. 
/// Bourdieu P. 2005b. Foreword, [w:] Professional Competation and Professional Power. Lawyers, Accountants and Social Construction of Markets, red. Y. Dezalay, D. Sugerman, Routledge, London, New York, s. ix-x.

/// Bourdieu P. 2005c. The Political Field, the Social Science Field, and the Journalistic Field, [w:] Bourdieu and the Journalistic Field, red. R.D. Benson, ÉrikNeveu, Cambridge, Polity, s. 29-47.

/// Bourdieu P. 2006. Medytacje pascaliańskie, tłum. K. Wakar, Oficyna Naukowa, Warszawa.

/// Bourdieu P. 2008. Zmyst praktyczny, tłum. M. Falski, Wydawnictwo Uniwersytetu Jagiellońskiego, Kraków.

/// Bourdieu P. 2009. Rozum praktyczny. O teorii działania, tłum. J. Stryjczyk, Wydawnictwo Uniwersytetu Jagiellońskiego, Kraków.

/// Bourdieu P. 2011. O telewiryi. Panowanie driennikarstwa, tłum. K. Sztandar-Sztanderska, A. Ziółkowska, Wydawnictwo Naukowe PWN, Warszawa. /// Bourdieu P., Boltanski L. 1976. La production de l'idéologie dominante, „Actes de la recherche en sciences sociales” 1976, 2 (2-3), s. 3-73.

/// Bourdieu P., Passeron J-C. 2006. Reprodukcja. Elementy teorii systemu nauczania, tłum. E. Neyman, Wydawnictwo Naukowe PWN, Warszawa.

/// Bourdieu P., Wacquant L.J. 1993. From Ruling Class to Field of Power: An Interview with Pierre Bourdien on La Noblesse d'État, „Theory, Culture \& Society" 1993, nr 10, s. 19-44.

/// Bourdieu P., Wacquant L.J. 2001. Zaproszenie do socjologii refleesyjnej, tłum. A. Sawisz, Oficyna Naukowa, Warszawa.

/// Broszkiewicz W. 2010. Kapitat kulturony młodego pokolenia Polski wspótczesnej. Studium na prayketadzie wybranych spoteczności Podkarpacia, Wydawnictwo Uniwersytetu Rzeszowskiego, Rzeszów.

/// Buchowski M. 2006. The Specter of Orientalism in Europe: From Exotic Other to Stigmatized Brother. „Anthropological Quarterly” 2006, 79, s. 463-482.

/// Burawoy M. 2009. O socjologie publiczna. Præemónienie presydenckie z roku 2004, tłum. A. Dziuban, [w:] Nowe perspektyny teorii socjologicznej, red. A. Manterys, J. Mucha, Zakład Wydawniczy NOMOS, Kraków, s. 525-561. /// Bukraba-Rylska I. 2004. Socjolog czasu transformacji - portret z. oddali, [w:] Zmiana csy stagnacja, red. M. Marody, Scholar, Warszawa, s. 153-174. 
/// Chałasiński J. 1958. Pržesz̧ość i prayyszłość inteligencji polskiej, Ludowa Spółdzielnia Wydawnicza, Warszawa.

/// Collins R. 2009. Conflict Sociology: A Sociological Classic Updated, Paradigm Publishers, London.

/// Domański H., Rychard A., Śpiewak P. 2005. Polska jedna czy miele? Trio, Warszawa.

/// Domański H., Tomescu-Dubrow I. 2008. Nierówności edukacyjne przed $i$ po zmianie systemu, [w:] Zmiany stratyfikacji spotecznej w Polsce, red. H. Domański, Wyd. IFiS PAN, Warszawa, s. 133-152.

/// Drahokoupil J. 2008. The rise of the comprador service sector: The politics of state transformation in Central and Eastern Europe, „Polish Sociological Review" 2008, 162, s. 175-189.

// E Éber R.Á. 2011. Which Duality? Why Dual? On the Gains and Losses of Hungarian Sociology's Dual Society Theories, „Review of Sociology” 2011, 4, s. 4-20.

/// Eyal G., Szelényi I., Townsley E.R., 1998. Making capitalism without capitalists. Class formation and elite struggles in post-communist Central Europe. Verso, London.

/// Gdula M., Sadura P. red. 2012. Style sycia i porzqdek klasowy w Polsce, Scholar, Warszawa.

/// Gella A., 1976. An Introduction to the Sociology of the Intelligentsia, [w:] The Intelligentsia and the intellectuals. Theory, method, and case study, A. Galla, Sage, London, Beverly Hills, s. 9-34.

/// Gorzelak G., Jałowiecki B., 2010. Sity lokalne i regionalne, [w:] Moderniracja Polski: Struktury, Agencje, Instytucje, red. W. Morawski, Wydawnictwa Akademickie i Profesjonalne, Warszawa, s. 501-523.

/// Gouldner A. 2010. Krysys zachodniej socjologii, tłum. P. Tomanek, Nomos, Kraków.

/// Grabowska M. 2004. Podział postkomunistycrny. Spoteczne podstawy politykei w Polsce po 1989 roku. Scholar, Warszawa.

// / Hryniewicz J. 2007. Stosunki pracy w polskich organizacjach, Scholar, Warszawa.

/// Jedlicki J. red., 2008. Drieje inteligencii polskiej do roku 1918, Instytut Historii PAN, Wydawnictwo Neriton, Warszawa. 
/// Kilias J. 2007. Swoistości socjologii polskiej z.perspektyny socjologa, „Societas/Communitas" 2007, 1(3), s. 189-199.

/// Kolasa-Nowak A. 2010. Zmiana systemowa w Polsce w interpretacjach socjologicznych, Wyd. UMCS, Lublin.

/// Krasnodębski Z. 2003. Demokracja peryferii, Słowo/Obraz Terytoria, Gdańsk.

/// Lamont M., Small M.L. 2008. How Culture Matters: Enrichingour Understanding of Poverty, [w:] The Colors of Poverty: Why Racial and Ethnic Disparities Persist, red. D. Harris, A. Lin, Russell Sage, New York, s. 76-102.

/// Loś M., Zybertowicz A. 2000. Privatizing the police-state. The case of Poland, St. Martin's Press, New York.

/// Marody M. red. 1991. Co nam zostało z tych lat? Spoteczeństwo polskie u progu zmiany systemowej, Aneks, Londyn.

/// Misztal B., Misztal B. 1984. The Explanatory Utility of Major Sociological Theories in Poland 1970-1980, „Sociology” 1984, 18, 239, s. 239-252.

/// Pilawski K. 2011. Gra w klasy. Z prof. Henrykiem Domańskim rozmawia Kraysztof Pilawski, „Przegląd” 2011, nr 20, http:/ /www.przeglad-tygodnik. $\mathrm{pl} / \mathrm{pl} /$ artykul/gra-klasy; dostęp: 30.07.2013.

// / Pinto L. 2009. Le café du commerce des penseurs. Á propos de la doxa intellectualle, Éditions du Croquant, Savoir/Agir, Paris.

/// Staniszkis J. 2006. Postkomuniż. Próba opisu, Słowo/Obraz Terytoria, Gdańsk.

/// Sułek A. 2011. „Do Amerykil!”. Polscy socjologowie w Stanach Zjednoczonych po 1956 roku i rozwój socjologii empirycznej w Polsce, [w:] tenże, Obrazy z. àycia socjologii w Polsce, Oficyna Naukowa, Warszawa, s. 96-141.

/// Sztompka P. 1993. Civilizational Incompetence: The Trap of Post-Communist Societies, „Zeitschriftfür Soziologie” 1993, Jg. 22, Heft 2, s. 85-95.

/// Sztompka P. 1995. Cultural and Civilizational Change: The Core of Post-communist Transition, [w:] Social Change and Modernization. Lessons from Eastern Europe, red. B. Grancelli, Walter de Gruyter, Berlin, New York, s. 233-248. /// Sztompka P. 2000. Trauma wielkiej zmiany, Wyd. ISP PAN, Warszawa. /// Sztompka P. 2011. Czy istnieje socjologia polska?, „Studia Socjologiczne” 2011, 2 (201), s 43-54.

/// Świda-Zięba H. 1994. Mentalność postkomunistyczna, „Kultura i społeczeństwo" 1994, nr 1, s. 35-50. 
/// Wacquant L.J.D. 2004. Critical thought as solvent of Doxa, „Constellations" 2004, 11 (1), s. 97-101.

/// Walicki A., 2005. Polish conception of the intelligentsia and its calling, [w:] Words, deeds and values. The intelligentsias in Russia and Poland during the nineteenth and twentieth centuries, F. Bjorling, A. Pereswetoff-Morath, Department of East and Central European Studies, Lund University, Lund, s. 1-22.

/// Wallerstein I. 1974. The Modern World System: Capitalist Agriculture and the Origins of the European World Economy in the Sixteenth Century, Academic Press, New York.

/// Warczok T. 2010. Kapitat ludqki - dekonstrukcja pojecia, [w:] Aktywizacja kapitatu ludzkiego - dylematy teorii a praktyka matych i średnich miast, red. A. Bartoszek, K. Czekaj, Wydawnictwo GWSH, Katowice, s. 13-27

/// Wąsowski M. 2012. Mitt Romney miat racje. Wsparcia państwa nymagaja od politykón ,ofiary losu”. Wywiad z prof. Henrykiem Domańskim http:// natemat.pl/32333, mitt-romney-mial-racje-wsparcia-panstwa-wymagajaod-politykow-ofiary-losu-wywiad; dostęp: 12.07.2013.

/// Weber M. 1995. Szkice z socjologii religii, tłum. J. Prokopiuk i H. Wandowski, Książka i Wiedza, Warszawa.

/// Weber M. 2002. Gospodarka i społeczeństwo. Zarys socjologii rozumiejacej, tłum. D. Lachowska, Wydawnictwo Naukowe PWN, Warszawa.

/// Wnuk-Lipiński E. 1991. Rozpad połowiczny. Szkice z socjologii transformacji ustrojowej, Wyd. IFiS PAN, Warszawa.

/// Zarycki T. 2009. The Power of the Intelligentsia. The Rywin Affair and the Challenge of Applying the Concept of Cultural Capital to Analyze Poland's elites. „Theory and Society” 2009, 38, s. 613-648.

/// Zybertowicz A. 2005. Anti-development interest groups (preliminary outline), „Polish Sociological Review” 2005, 1, s. 69-90.

/// Zybertowicz A. 2006. Intelektualny rdzeń państwa, „Życie Warszawy” 2006, 7 czerwca 2006.

/// Zybertowicz. A. 2010. Socjologowie w pułapce. „Rzeczpospolita” 2010, 25-26 września. 


\section{/// Abstrakt}

Artykul rysuje szerszy kontekst społeczny funkcjonowania socjologii w Polsce. Autorzy odwołują się w tym celu w pierwszej kolejności do metodologii Pierre'a Bourdieu, rekonstruując w ogólnych zarysach pozycje pola socjologicznego w szerszym polu władzy, a także specyficzne cechy tego ostatniego. Należy do nich w ich przekonaniu dominacja kapitału kulturowego nad ekonomicznym i związana z tym hegemonia szeroko rozumianej inteligencji. Ważną cechą polskiego pola władzy jest też jego charakterystyczny dla krajów peryferyjnych podział na część zorientowana na integrację z globalnym centrum i część stawiającą mu względny, głównie kulturowy, opór. Podział ten przenosi się również wyraźnie na pole socjologiczne, co jest związane z ograniczoną autonomią tego ostatniego i owocuje między innymi znacząca w Polsce przewaga nurtu socjologii publicznej nad nurtem socjologii krytycznej.

Słowa kluczowe:

socjologia polska, socjologia krytyczna, socjologia publiczna, Bourdieu, kapitał kulturowy

\section{/// Abstract}

The paper draws a picture of a wider social context of functioning of sociology in Poland. Authors rely primarily on the methodology of Pierre Bourdieu to achieve this aim. In particular they reconstruct the general position of the sociological field in relation to the wider field of power and the specific characteristic of the later. They include, as the authors see them, domination of the cultural capital over the economic capital and the resulting hegemony of the intelligentsia in the field of power. Another important characteristic of the Polish field of power, which seems typical for most peripheral societies, is its division on to one part orientated towards the integration with the global core and its other part challenging the global domination, though, mostly in the cultural sphere. This division is also clearly transmitted into the structure of the sociological field, given its relatively restricted autonomy and results in a strong superiority of public sociology over the weakly developed critical sociology.

Keywords:

sociology in Poland, critical sociology, public sociology, Bourdieu, cultural capital 